\title{
ADHESION MODELS FOR ANALYSIS OF THE TROPICAL ECOSYSTEM DIAMETRIC STRUCTURE
}

\author{
André Luiz Nascimento Parcial \\ Observatório Urbano do Estado do Rio de Janeiro - OUERJ/UERJ/UN-Habitat \\ $\triangle$ andrenascimento.biouerj@gmail.com \\ Elizabeth dos Santos Rios \\ Observatório Urbano do Estado do Rio de Janeiro - OUERJ/UERJ/UN-Habitat \\ Thamires Henrique Teles da Silva \\ Observatório Urbano do Estado do Rio de Janeiro - OUERJ/UERJ/UN-Habitat \\ Josimar Ribeiro de Almeida \\ Observatório Urbano do Estado do Rio de Janeiro - OUERJ/UERJ/UN-Habitat
}

\begin{abstract}
:
In order to prove the validity of the dominance expression as a function of basal area, according to Cain et al. (1956), six mathematical models were tested. The models tested were: $\mathrm{Dcp}=\mathrm{a}+\mathrm{b}(\mathrm{d} 1,3)+\mathrm{c}(1 / \mathrm{d} 1,3) ; \mathrm{Dcp}=\mathrm{a}+\mathrm{b}(\mathrm{d} 1,3)+\mathrm{c}(\mathrm{d} 1,3) 2 ; \mathrm{Dcp}=\mathrm{a}+\mathrm{b}(\mathrm{d} 1,3) ;$ Dcp $=\mathrm{a}+$ $\mathrm{b}(1 / \mathrm{d} 1,3)$; Dcp $=\mathrm{a}+\mathrm{b}(\mathrm{d} 1,3) 2$; and $\mathrm{Dcp}=\mathrm{a}+\mathrm{b}(\log \mathrm{d} 1,3)$; which: Dcp = crown diameter; $\mathrm{d} 1,3=$ diameter at $1,30 \mathrm{~m}$ from the soil, ou diameter at breast height $(\mathrm{DBH})$ e a.b.c $=$ coefficients of the regression equation. Proven DCP / d1, 3 relation, it was calculated the basal area $(\mathrm{G})$, which is the sum of the cross-section $(\mathrm{g})$ of each tree bole of a species, expressed per unit area, in this case hectare.

There is a strong correlation between crown diameter (DcP) and diameter at breast height $(\mathrm{DBH})$ in the studied forest. Among five models tested, only two, DcP $=\mathrm{a}+\mathrm{b}(1 / \mathrm{d} 1,3)$ e Dcp $=\mathrm{a}+\mathrm{b}(\operatorname{Iog} \mathrm{d} 1,3)$, not exhibit good degree of adjustment, should not be used in this type of forest. The values of $\mathrm{r}^{2}$ above 0,70 show that is possible use DBH and therefore the basal area to express the dominance, mainly considering the relation crown diameter /DBH is very specific.
\end{abstract}

Keyword: Mathematical Models, Diametric Structure, Tropical Ecosystem.

\section{ADERÊNCIA DE MODELOS PARA ANÁLISE DA ESTRUTURA DIAMÉTRICA DE ECOSSISTEMA TROPICAL}

\section{Resumo:}

Para comprovar a validade da expressão da dominância em função da área basal, conforme sugerido por Cain et al. (1956), foram testados seis modelos matemáticos. Os modelos testados foram os seguintes: Dcp $=a+b\left(d_{1,3}\right)+c\left(1 / d_{1,3}\right)$; Dcp $=a+b\left(d_{1,3}\right)+c\left(d_{1,3}\right)^{2}$; Dcp $=a+b\left(d_{1,3}\right) ; D c p=a+b\left(1 / d_{1,3}\right) ; D c p=a+b\left(d_{1,3}\right)^{2} ;$ e Dcp $=a+b\left(\log d_{1,3}\right)$; onde: Dcp = diâmetro da copa; $\mathrm{d}_{1,3}=$ diâmetro a $1,30 \mathrm{~m}$ do solo, ou diâmetro à altura do peito (DAP); e a.b.c $=$ coeficientes da equação de regressão. Comprovada a relação Dcp / $\mathrm{d}_{1,3}$, calculou-se a área basal $(\mathrm{G})$, que é a somatória das secções transversais (g) dos fustes de cada árvore de uma espécie, expressa por unidade de área, neste caso o hectare. 
Existe forte correlação entre o diâmetro das copas (Dcp) e o DAP na floresta estudada. Dos 5 modelos testados, somente dois, $D c P=a+b\left(1 / d_{1,3}\right)$ e $\operatorname{Dcp}=a+b\left(\log d_{1,3}\right)$, não apresentam bom grau de ajuste, não devendo ser utilizados nesse tipo de floresta. Os valores de $\mathrm{r}^{2}$ acima de 0,70 indicam que é possível utilizar-se o DAP e portanto a área basal para expressar a dominância, principalmente considerando que a relação diâmetro da copa/DAP é muito específica.

Palavras-chave: Modelos matemáticos, Estrutura diamétrica e Ecossistema tropical.

\section{INTRODUCTION}

The diametric structure has been evaluated through the diameter distribution of the number of individuals by Finol (1964, 1969), Veja (1966, 1968), and besides through diametric distribution of basal area and volum Longhi (1980), can be made for isolated species or a forest as a whole. When the analysis includes isolated species, according Finol (1969), few are those with regular diametric distribution, as defined by Finol $(1964,1969)$ and Veja $(1966,1968)$. By the other hand, when it is analyzed the structure of native tropical forests, they usually have a regular shape, which, according Finol (1969) and Veillon et aI. (1976) is due to the large number of individuals of the species that occur only in the lower classes, which correspond to $25 \%$ of the total species.

Rollet (1974) distinguishes six types of diametric distribution for the species of rainforest, relating them to the different light requirements of each species, and states that the species categories of sub grove species in exponential balance (with large amplitude variation of $\mathrm{DBH}$ ) represent almost $90 \%$ of species with $\mathrm{DBH}$ more than $10 \mathrm{~cm}$, then the species category with abundant regeneration and balance, so called builders forest.

\section{MATERIALS AND METHODS}

To review the sampling Husch et al. (1972) mention within the random processes, the process of sampling in two stages, that is a limited random process, where the second stage of sampling is restricted or dependent on the first stage. Its main advantage is the reduction of costs resulting from the concentration of subsampling within primary units. In this process, the primary and secondary sampling units are pre-defined in shape and size. Higuchi et al. (1982) tested several sizes of sample plots, concluding that the rectangular plots show better results than the square ones and can be used in general installments of up to $40 \mathrm{~m}$ wide by 150 m long. For Lamprecht (1964) the sample size for structural studies should be not less than 1 hectare, varying the shape, however recommended to use samples from $20 \mathrm{~m}$ to $500 \mathrm{~m}$ as 
standard. Samples of smaller units will not have the same efficacy in tropical forests.

The target population of this study consists of vegetation cover compounded of individuals with total height $(\mathrm{h})$ more than or equal to $10 \mathrm{~cm}$, which implies a large amplitude distribution. The sample was divided into three levels of approach, depending on the size of individuals, thus there are: Level I - To approach individuals with total height more than or equal to $10 \mathrm{~cm}$ and DBH less than $5 \mathrm{~cm}$; Level II - To approach individuals with DBH more than or equal to $5 \mathrm{~cm}$ and less than $20 \mathrm{~cm}$. Level III - To approach individuals with DBH more than or equal to $20 \mathrm{~cm}$.

For Level I of approach, it was used bands of $2 \mathrm{~m}$ wide and $100 \mathrm{long}$, which are the primary units, divided into plots of $2 \mathrm{~m} .10 \mathrm{~m}$ (secondary units), which in turn were divided into square plots of $2 \mathrm{~m}$ side. Sample units used in Level II consisted of bands of $10 \mathrm{~m}$ wide and $100 \mathrm{~m}$ long (secondary units) located in the middle of the unit of $20 \mathrm{~m}$ by $500 \mathrm{~m}$ of level III (primary units) and divided into square plots of $10 \mathrm{~m}$ side. The shape and size of the sample units of level III have previously been established, based on the shape and size proposed by Lamprecht (1964) and Finol (1971). Thus, bands of 1 hectare, with $20 \mathrm{~m}$ wide and $500 \mathrm{~m}$ long, divided into plots of $20 \mathrm{~m}$ by $100 \mathrm{~m}$, and these in subplots of $10 \mathrm{~m} \times 20 \mathrm{~m}$.

The secondary sample units level II were randomly drawn and distributed within the sample units of Level III, and secondary units of Level I were randomly drawn and randomly distributed within the secondary level II units, thus characterizing the sampling process in two stages described by Husch et aI. (1972). The preliminary sampling consisted of measuring 30 units of level III , 25 secondary units at Level II and 100 secondary units at level I. From the data collected in this preliminary sampling, the optimal sampling intensity was calculated to quantitatively approach of the population. The suitable approach qualitatively, ie , to approach the floristic composition of settlement intensity was obtained by species area curve Oosting (1951) .

The horizontal structure is represented by those parameters that indicate the occupation of land by the species in the horizontal direction of the forest. Therefore, to represents the values of relative abundance, relative dominance and relative frequency, obtained on the adult population, ie, formed of individuals with DBH more than or equal to 20 cm, which were approached by level III, according to proposition Lamprecht (1964). To prove the validity of the expression of dominant in function of the basal area as suggested by Cain et al. (1956), six mathematical models were tested. The models tested were as follows: Dcp $=a+b(d 1,3)+c(1 / d 1,3) ; D c p=a+b(d 1,3)+c(d 1,3) 2 ;$ Dcp $=a+b(d 1,3) ;$ Dcp $=a+$ 
b (1/ d1,3); Dcp = a + b (d1,3)2; e Dcp = a + b (log d1,3); which: Dcp = crown diameter; d1,3 $=$ diameter at $1,30 \mathrm{~m}$ from the soil, ou diameter at breast height $(\mathrm{DBH})$ e a.b.c $=$ coefficients of the regression equation. Proven the relation Dcp / d1,3, it was calculated the basal area $(G)$, which is the sum of the cross sections $(\mathrm{g}$ ) the bole of each tree of a kind, expressed per unit area, in this case hectare.

To calculate the individual cross-section was used corresponding to the center of each diametric class, through the expression $g=\Pi d^{2} / 4$, which allowed the preparation of a table (Table 1) to calculate the basal area of each morphospecies, whose value was obtained by sum of the product of cross-sectional of each diametric class by the number of individuals of morphospecies in this class.

Table 1 - Individual Cross - Section

\begin{tabular}{ccc}
\hline Diametric Class $(\mathrm{cm})$ & $\begin{array}{c}\text { Central Class } \\
\mathrm{d}_{1,3}(\mathrm{~cm})\end{array}$ & $\mathrm{g}=\underline{\Pi \mathrm{d}^{2}} \underline{1.3}$ \\
& 25 & 0,053 \\
$30-29,9]$ & 35 & 0,089 \\
$40-49,9]$ & 45 & 0,163 \\
$50-59,9]$ & 55 & 0,245 \\
$60-69,9]$ & 65 & 0,354 \\
$70-79,9]$ & 75 & 0,452 \\
$80-89,9]$ & 85 & 0,601 \\
$90-99,9]$ & 95 & 0,703 \\
100 & 105 & 0,872 \\
\hline
\end{tabular}

To obtain the absolute frequency of level I, it was considered five plots of $2 \mathrm{~m} \times 10 \mathrm{~m}$ as a sample. Thus, each plot occupied by the species is $0.2(20 \%)$ of absolute frequency. Since the pattern unit of structural analysis is a sample of 1 hectare $(20 \mathrm{~m} \times 500 \mathrm{~m})$, which were measured in 3 groups of 5 plots of $2 \mathrm{~m} \times 10 \mathrm{~m}$, the absolute frequency level I is given by the arithmetic average of the values of samples or groups of 5 splots.

To obtain the absolute frequency of level II, it was considered samples of $10 \mathrm{mx} 100$ $\mathrm{m}$, divided into square plots $10 \mathrm{~m}$ of side. Each plot occupied by the species is $0.1(10 \%)$ of 
absolute frequency. Three samples were measured with 10 plots, the absolute frequency of level II by the arithmetic average of the samples or groups of 10 plots.

\section{RESULTS AND DISCUSSION}

The statistical analysis of the level III provided the parameter estimates frequency and basal area.

Table 1 - Frequency and basal area

\begin{tabular}{ccccc}
\hline Parameter & $\mathrm{x}$ & $\mathrm{s}$ & $\mathrm{s} \bar{x}$ & $\mathrm{CV}(\%)$ \\
\hline $\begin{array}{c}\text { Frequency } \\
\left(\mathrm{n}^{\circ} \text { of }\right. \\
\text { individuals })\end{array}$ & 189,462 & 12,953 & 3,578 & 6,25 \\
\hline $\begin{array}{c}\text { Basal Area } \\
\left(\mathrm{m}^{2} / \text { há }\right)\end{array}$ & 23,043 & 1,753 & 0,095 & 5,06 \\
\hline
\end{tabular}

Confidence intervals (CI) for the average frequency and basal area, also obtained from the analysis are: Frequency $(\mathrm{CI})=177.871<\bar{x}<219.424=\mathrm{P} 0,05$ and basal area $(\mathrm{CI})=$ $22,574<\bar{x}<27,417=\mathrm{P} 0,05$. Table 2 shows the analysis of variance for the data obtained at level II of approach.

Table 2 - Analysis of variance for level II of approach

\begin{tabular}{ccccc}
\hline Source & GL & SQ & MQ & F \\
\hline Between & 7 & 2572,823 & 384,875 & $1,676 \bar{n} \mathrm{~s}$ \\
UP & & & & \\
Inside UP & 16 & 4217,692 & 285,645 & \\
Total & 23 & 6678,857 & & \\
& & & &
\end{tabular}

F 7/16 $=2,66$

0,05

From the data analysis were obtained the following parameter estimates: average ( $\mathrm{x}$ ) $=1225.342$ individuals / ha ; Variance between $\operatorname{UP}\left(s^{2} e\right)=41,217$; Variance among $\operatorname{UP}\left(s^{2} d\right)=$ 255,712 , and standard error $\left(s^{2} x\right)=3,947$. The confidence interval ( CI) for the mean number 
of individuals per $1000 \mathrm{~m}^{2}$, this fraction of the population with DBH between $5 \mathrm{~cm}$ and $20 \mathrm{~cm}$ is $\mathrm{CI}=108,963<\bar{x}<128,262=\mathrm{P} 0,05$. There is no significant difference between the primary units of level II of approach, with greater variation within the primary units, ie, between secondary sampling units, which recommends the use of random sampling process for this fraction of forests. For forests with this structure, the results of the statistical analysis of the sampling process in two stages show that for the same area (200 ha ), the number of 6 to primary units with 1 hectare, each one with three secondary units with $1000 \mathrm{~m}$, are sufficient to quantitatively evaluate the population with $\mathrm{DBH}$ more than or equal to $5 \mathrm{~cm}$ less than $20 \mathrm{~cm}$.

Table 3 presents the analysis of variance for the data obtained in level I of approach. The analysis was performed for four fractions of the forest: total population, population without lianas, population without palm trees and population without lianas and palms.

Table 3 - Analysis of variance for the level I of approach

\begin{tabular}{|c|c|c|c|c|c|}
\hline POPULATION & SOURCE & GL & SQ & MQ & $\mathrm{F}$ \\
\hline \multirow{3}{*}{ TOTAL } & Between & 25 & 345345,776 & 381784,281 & 1,952 \\
\hline & Inside & 98 & 245825,881 & 2493,533 & \\
\hline & Total & 100 & 301516,787 & & \\
\hline \multirow{3}{*}{$\begin{array}{l}\text { WITHOUT } \\
\text { LIANA }\end{array}$} & Between & 25 & 23992,698 & 169948,650 & $1,623^{*}$ \\
\hline & Inside & 99 & 112062,156 & 1145,928 & \\
\hline & Total & 100 & 154057,787 & & \\
\hline \multirow{3}{*}{$\begin{array}{l}\text { WITHOUT } \\
\text { PALM TREE }\end{array}$} & Between & 25 & 76976,667 & 3487,244 & 1,653 \\
\hline & Inside & 97 & 280262,852 & 2233,982 & \\
\hline & Total & 100 & 305061,773 & & \\
\hline \multirow{3}{*}{$\begin{array}{l}\text { WITHOUT } \\
\text { LIANA AND } \\
\text { PALM TREE }\end{array}$} & Between & 25 & 34171,238 & 1487,574 & 1,515 \\
\hline & Inside & 97 & 98507,345 & 989,644 & \\
\hline & Total & 100 & 18272,213 & & \\
\hline
\end{tabular}

$\mathrm{F}_{23,96} \cong \mathrm{F}_{24,120}=1,61$

$0,050,05$ 
From the analysis the results, the parameter estimates of the population for each fraction thereof were obtained.

Table 4 - Parameters of the population

\begin{tabular}{ccccc}
\hline POPULATIONS & $\bar{x} / 20 \mathrm{~m}^{2}$ & $\mathrm{~s}^{2} \mathrm{e}$ & $\mathrm{s}^{2} \mathrm{~d}$ & $\mathrm{~s}^{2} \mathrm{x}$ \\
\hline Total Population & 142,764 & 176,386 & 2438,524 & 4,302 \\
$\begin{array}{c}\text { Population without } \\
\text { Liana }\end{array}$ & 113,715 & 103,211 & 1056,836 & 2,989 \\
$\begin{array}{c}\text { Population without } \\
\text { Palm tree }\end{array}$ & 129,718 & 189,864 & 2322,902 & 4,142 \\
$\begin{array}{c}\text { Population without } \\
\text { Liana and Palm tree }\end{array}$ & 90,913 & 90,689 & 95,688 & 2,729 \\
\hline
\end{tabular}

In Table 5, the results of the regression analysis are presented of the 6 tested mathematical models to express Dcp / DBH ratio.

Table 5 - Regression analysis of the relation Dcp / DBH

\begin{tabular}{cccccc|c|c}
\hline Pattern & $\mathrm{a}$ & $\mathrm{b}$ & $\mathrm{c}$ & $\mathrm{r}^{2}$ & $\mathrm{sxy}$ & $\mathrm{IF}(\mathrm{sxy} \%)$ \\
\hline $\begin{array}{c}\text { Dcp }=\mathrm{a}+\mathrm{b} \\
\left(\mathrm{d}_{1,3}\right)+\mathrm{c}(1 /\end{array}$ & 3,220 & 13,287 & $-0,065$ & 0,730 & 2,287 & 36,351 \\
$\left.\mathrm{~d}_{1,3}\right)$ & & & & & & \\
$\begin{array}{c}\text { Dcp }=\mathrm{a}+\mathrm{b} \\
\left(\mathrm{d}_{1,3}\right)+\mathrm{c}\left(\mathrm{d}_{1,3}\right)^{2}\end{array}$ & 2,196 & 16,552 & $-2,012$ & 0,734 & 2,038 & 28,822 \\
$\begin{array}{c}\text { Dcp }=\mathrm{a}+\mathrm{b} \\
\left(\mathrm{d}_{1,3}\right)\end{array}$ & 2,722 & 13,867 & & 0,728 & 2,957 & 29,091 \\
$\begin{array}{c}\text { Dcp }=\mathrm{a}+\mathrm{b}(1 / \\
\left.\mathrm{d}_{1,3}\right)\end{array}$ & 10,317 & $-0,700$ & & 0,333 & 3,223 & 45,582 \\
$\begin{array}{c}\text { Dcp }=\mathrm{a}+\mathrm{b}(1 / \\
\left.\mathrm{d}_{1,3}\right)^{1 / 2}\end{array}$ & $-2,597$ & 18,251 & & 0,713 & 2,112 & 29,872 \\
$\begin{array}{c}\text { Dcp }=\mathrm{a}+\mathrm{b} \\
\left(\text { Log } \mathrm{d}_{1,3}\right)\end{array}$ & 13,268 & 10,352 & & 0,581 & 2,553 & 36,112 \\
\hline
\end{tabular}

$\mathrm{d}_{1,3}=$ diameter at the breast height (DBH) at 1,30m from the floor.

Dcp $=$ crown diameter.

$\mathrm{a}, \mathrm{b}, \mathrm{c}=$ coefficients of the regression.

$\mathrm{IF}(\operatorname{sxy} \%)=$ Furnival index. 
The results presented in Table 5 show that there is strong correlation between the diameter of the cups (Dcp) and the DBH in the forest studied. Within 6 models tested, only two, DcP $=\mathrm{a}+\mathrm{b}\left(1 / \mathrm{d}_{1,3}\right)$ and $\mathrm{Dcp}=\mathrm{a}+\mathrm{b}\left(\operatorname{Iog} \mathrm{d}_{1,3}\right)$, do not show a good degree of adjustment. The $\mathrm{r}^{2}$ values above 0.70 indicate that it is possible to use the $\mathrm{DBH}$ and therefore the basal area to express dominance, especially considering that the diameter ratio of the pantry / DBH is very specific. Thus one can use the model Dcp $=a+b\left(d_{1,3}\right)+\left(d_{1,3}\right)^{2}$ to ratify the expression of dominance as a function of basal area.

\section{BIBLIOGRAPHY}

CAIN, S. A.; CASTRO, G. M. O.; PIRES, J. M.; SILVA, N. T.. Application of some phytosociological tecniques to Brazilian rain forest. American Journal Of Botany, St. Louis, v. 10, n. 43, p.911-941, 1956.

CARVALHO, J. O. P.. Análise estrutural da regeneração natural em floresta tropical densa na Região do Tapajós no Estado do Pará. 1982. 63 f. Dissertação (Mestrado) - Curso de Ciências Florestais, Universidade Federal do Paraná, Paraná, 1982.

FINOL, U. H.. Estudio silvicultural de algumas especies comerciales en el bosque universitario "El Caimital" Estado Barinas. Revista Forestal Venezolana, Merida, v. 7, n. 10 - 11, p. 17 - 63, 1964.

FINOL, U. H.. Possibilidades de manejo silvicultural para las reservas forestales de la Region Occidental. Revista Forestal Venezolana, Merida, v. 12, n. 17, p. 81 - 100, 1969.

FINOL, U. H.. Nuevos parametros a considerarse en el analisis estrutural de las selvas virgenes tropicales. Revista Forestal Venezolana, Merida, v. 14, n. 21, p. 29 - 42, 1971.

HIGUCHI, N.; SANTOS, J.; JARDIM, F. C. S.. Tamanho de parcelas amostrais para inventários florestais. Acta Amazonica, Manaus, v. 12, n. 1, p.91-103, 1982.

HUSCH, B.; MILLER, C. I.; BEERS, T. W.. Forest mensuration. Nova Iorque: The Ronald Press, 1972.

LAMPRECHT, H. Ensayo sobre la estructura floristica de la parte suroriental del Bosque Universitário "EI caimital", Estado Barinas. Revista Forestal Venezolana, Merida, v. 7, n. 10 - 11, p. 77 - 119, 1964.

VEJA, C. L.. Observaciones ecologicas sobre los bosques de roble de la sierra Boyacá, Colombia. Turrialba, San José, v. 16, n. 3, p.286-296, 1966.

VEJA, C. L.. La estructura y composicion de los bosques humedos tropicales del Carare, Colornbia. Turrialba, San José, v. 18, n. 4, p.416-436, 1968.

VEILLON, J.; KONRAD, V. W.; GARCIA, N.. Estudio de la masa forestal y su dinamismo en parcelas de diferentes tipos ecológicos de bosques naturales de las tierras bajas venezolanas. Revista Forestal Venezolana, Merida, v. 19, n. 26, p. 73 - 106, 1976. 